\title{
Vagus Nerve and Stomach Synucleinopathy in Parkinson's Disease, Incidental Lewy Body Disease and Normal Elderly Subjects: Evidence Against the "Body-First" Hypothesis
}

\author{
Thomas G. Beach ${ }^{\mathrm{a}}$, Charles H. Adler ${ }^{\mathrm{b}}$, Lucia I. Sue ${ }^{\mathrm{a}}$, \\ Holly A. Shill ${ }^{\mathrm{c}}$, Erika Driver-Dunckley ${ }^{\mathrm{b}}$, Shyamal H. Mehta ${ }^{\mathrm{b}}$, Anthony J. Intorcia ${ }^{\mathrm{a}}$, \\ Michael J. Glass ${ }^{\mathrm{a}}$, Jessica E. Walker ${ }^{\mathrm{a}}$, Richard Arce ${ }^{\mathrm{a}}$, \\ Courtney M. Nelson ${ }^{\mathrm{a}}$ and Geidy E. Serrano ${ }^{\mathrm{a}}$

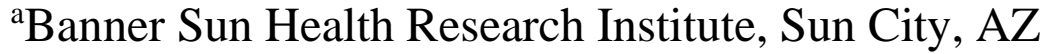 \\ ${ }^{b}$ Mayo Clinic College of Medicine, Mayo Clinic Arizona, Scottsdale, AZ \\ ${ }^{\mathrm{c}}$ Barrow Neurological Institute, Phoenix, AZ
}

Running Title: Vagus and Stomach Synucleinopathy

Key Words: pathology; etiology; autopsy; gastrointestinal; peripheral nerve; pathogenesis

Correspondence to: Thomas G. Beach, Banner Sun Health Research Institute, 10515 West Santa Fe Drive, Sun City, AZ 85351;

Telephone: 623-832-5643

Fax: 623-815-2960

thomas.beach@bannerhealth.com 
medRxiv preprint doi: https://doi.org/10.1101/2020.09.29.20204248; this version posted December 8, 2020. The copyright holder for this preprint

(which was not certified by peer review) is the author/funder, who has granted medRxiv a license to display the preprint in perpetuity.

It is made available under a CC-BY-NC-ND 4.0 International license .

\section{ABSTRACT}

Braak and others have proposed that Lewy-type $\alpha$-synucleinopathy (aSyn) in Parkinson's disease (PD) may arise from an exogenous pathogen that passes across the gastric mucosa and then is retrogradely transported up the vagus nerve to the medulla. We tested this "body-first" hypothesis by immunohistochemically staining stomach and vagus nerve tissue from an autopsy series of 111 normal elderly subjects (no brain aSyn), 33 with incidental Lewy body disease (ILBD) (brain aSyn without clinical parkinsonism or dementia) and 53 with PD. Median disease duration for the PD group was 13 years. Vagus nerve samples were taken adjacent to the carotid artery in the neck. Stomach samples were taken from the gastric body, midway along the greater curvature. Formalin-fixed paraffin-embedded sections were immunohistochemically stained for $\alpha$-synuclein phosphorylated at serine-129. In the vagus nerve none of the 111 normal subjects had aSyn in the vagus, while 12/26 ILBD (46\%) and 32/36 PD (89\%) subjects were aSyn-positive. In the stomach none of the 102 normal subjects had aSyn while 5/30 (17\%) ILBD and 42/52 (81\%) of PD subjects were aSyn-positive. As there was no aSyn in the vagus nerve or stomach of subjects without brain aSyn, these results support initiation of aSyn in the brain. The presence of aSyn in the vagus nerve and stomach of a subset of ILBD cases indicates that progression of synucleinopathy to the peripheral nervous system may occur at preclinical stages of Lewy body disease. 
medRxiv preprint doi: https://doi.org/10.1101/2020.09.29.20204248; this version posted December 8, 2020. The copyright holder for this preprint (which was not certified by peer review) is the author/funder, who has granted medRxiv a license to display the preprint in perpetuity.

It is made available under a CC-BY-NC-ND 4.0 International license .

\section{INTRODUCTION}

Since the discovery of $\alpha$-synuclein (aSyn) as the major constituent of Lewy bodies, sensitive immunohistochemical (IHC) methods have demonstrated that the brain and peripheral nervous system (PNS) distribution and density of Lewy bodies and their associated abnormal neurites are much greater than formerly appreciated [1-4]. Furthermore, the common PNS occurrence of aSyn pathology has instigated a proliferation of research aimed at using PNS aSyn as a biopsy biomarker as well as raising the critical question as to whether or not aSyn begins in the brain or within the periphery [5-47]. The stimulus for the latter alternative, which might be called the "body-first" hypothesis, has come largely from clinical studies of PD that have found a wide range of non-motor signs and symptoms that accompany or may even precede the motor signs [48-50]. Many of these non-motor accompaniments are related to gastrointestinal (GI) dysfunction and therefore much attention has been focused on the stomach as the major "first stop" along the alimentary tract $[43,51,52]$ and hence the most likely place for aSyn initiation, perhaps by absorption of toxins or through microbial or inflammatory stimuli, followed by transmission to the brain through the vagus nerve.

Supporting this is the repeatedly-confirmed finding of a rostrocaudal GI gradient of aSyn $[1,12,14,31]$, which may itself be related to the known distribution of vagal GI innervation [53]. A stomach-vagal-brain connection has been invoked to explain reports that subjects with prior vagotomy may have a lower prevalence of PD, although this has been disputed [54-59]. A stomach "inoculation" site has now been experimentally tested in multiple animal models, and a consensus seems to have emerged that in fact there may be bidirectional spread both upwards from the stomach and downwards from the brainstem [60-62].

A major piece of evidence for the body-first hypothesis, however, has been lacking, in that human autopsy studies have never found pathology-specific forms of aSyn in the stomach or other GI location in the absence of such aSyn in the brain. Also, previous autopsy studies have focused on the GI tract itself but not on the supposed gut-to-brain conduit, the vagus nerve. It has been rightfully argued that since 
medRxiv preprint doi: https://doi.org/10.1101/2020.09.29.20204248; this version posted December 8, 2020. The copyright holder for this preprint (which was not certified by peer review) is the author/funder, who has granted medRxiv a license to display the preprint in perpetuity. It is made available under a CC-BY-NC-ND 4.0 International license .

nervous tissue is much less concentrated in enteric walls than in CNS tissue, the apparent primacy of brain aSyn may only be due to its much greater endowment in this respect. The vagus nerve is, like CNS tissue, $100 \%$ nervous, and if it does serve as the connection through which aSyn makes its first passage from gut to brain, it, as well as a GI location, should be affected in a small percentage of normal subjects as the only manifestation of $\alpha$-synuclein pathology. About $25 \%$ of clinically normal elderly subjects have a limited brain distribution of aSyn, most often in the olfactory bulb, brainstem and/or amygdala. These “incidental Lewy body disease” (ILBD) subjects also have reduced striatal dopaminergic markers [63-65], suggesting that they represent prodromal PD or dementia with Lewy bodies (DLB). If aSyn begins in the stomach and then passes through the vagus nerve to the brain, it might be expected that a similar percentage of normal older people would show aSyn limited to stomach and/or vagus nerve, but lacking aSyn in the CNS.

\section{MATERIALS AND METHODS}

\section{Human subjects}

The study took place at Banner Sun Health Research Institute (BSHRI), which is part of Banner Health, a non-profit healthcare provider centered in Phoenix, Arizona. BSHRI and the Mayo Clinic Arizona are the principal members of the Arizona Parkinson's Disease Consortium. Brain necropsies and neuropathological examinations were performed on elderly subjects who had volunteered for the Arizona Study of Aging and Neurodegenerative Disorders (AZSAND)/BSHRI Brain and Body Donation Program (BBDP) [66]. The BBDP has been approved by designated BSHRI Institutional Review Boards and all subjects or their legally-authorized representative signed written informed consent. The majority of BBDP subjects are clinically characterized at BSHRI with annual standardized test batteries that include movement disorders and cognitive/neuropsychological components. Additionally, private medical records are requisitioned and reviewed for each subject and a postmortem questionnaire is conducted with 
medRxiv preprint doi: https://doi.org/10.1101/2020.09.29.20204248; this version posted December 8, 2020. The copyright holder for this preprint (which was not certified by peer review) is the author/funder, who has granted medRxiv a license to display the preprint in perpetuity.

It is made available under a CC-BY-NC-ND 4.0 International license .

subject contacts to help determine the presence or absence of dementia and parkinsonism for those subjects that did not have a recent standardized antemortem evaluation.

Subjects received complete neuropathological examinations while blinded to clinical diagnoses as described previously [66]. Specific consensus diagnostic criteria were used for PD, requiring 2 of 3 cardinal signs of rest tremor, rigidity or bradykinesia as well as substantia nigra aSyn and pigmented neuron loss at autopsy. Subjects with any brain aSyn but who lacked dementia or parkinsonism were termed incidental Lewy body disease (ILBD).

Case selection was done by searching the BBDP database for all those that had died and had a full clinical evaluation and full autopsy including vagus nerve and/or stomach sampling with immunohistochemical staining for phosphorylated $\alpha$-synuclein. Vagus nerve samples were taken adjacent to the midpoint of the carotid artery in the neck while stomach samples were taken midway along the greater curvature.

\section{Histological methods}

The process leading to the choice and evaluation of immunohistochemical methods for demonstrating pathological $\alpha$-synuclein has been described in previous publications $[16,67-70]$. The standard method used at AZSAND employs proteinase $\mathrm{K}$ pretreatment, which not only results in superior epitope exposure but also may assist with the pathological specificity of the stain by digesting normal, non-aggregated $\alpha$-synuclein, which is abundant in all nervous tissue. Using an antibody specific for $\alpha$ synuclein phosphorylated at serine 129 (pSyn)[71-75] also helps identify stained structures as pathological since normal control subjects do not have pSyn-immunohistochemically positive brain tissue elements [4,76]. Complete details of the staining procedure have been previously described [77] and so only a brief description is given here. 
medRxiv preprint doi: https://doi.org/10.1101/2020.09.29.20204248; this version posted December 8, 2020. The copyright holder for this preprint (which was not certified by peer review) is the author/funder, who has granted medRxiv a license to display the preprint in perpetuity. It is made available under a CC-BY-NC-ND 4.0 International license.

From each postmortem subject, three sections from vagus nerve and three sections of stomach were stained and examined. Formalin-fixed, paraffin-embedded 5-7 $\mu \mathrm{m}$ sections were deparaffinized and treated with 1:100 proteinase K (Enzo Life Sciences, Farmingdale, NY) at $37^{\circ} \mathrm{C}$ for 20 minutes, followed by suppression of endogenous peroxidase activity with $1 \%$ hydrogen peroxide for 30 minutes, incubation in primary antibody against $\alpha$-synuclein phosphorylated at serine 129, diluted 1:10,000 [72-75], incubation in biotinylated secondary antibody, avidin-biotin peroxidase complex (ABC, Vector Laboratories; Burlingame, CA) and 3,3'-diaminobenzidine (DAB; Sigma, St. Louis, MO) with saturated nickel ammonium sulfate and imidazole. All solutions subsequent to proteinase K, and all wash steps, excluding DAB incubation, were carried out in 0.1 M PBS with 0.3\% Triton X-100, pH 7.4. Sections were then counterstained in $1 \%$ Neutral Red. Positive neuronal perikarya and nerve fibers are bluish-black while background and negative tissue structures are red. Cases were staged with the Unified Staging System for Lewy Body Disorders (USSLB) [3,4].

\section{Statistical tests}

Group proportions in the three diagnostic groups were compared with chi-square tests. Group means were compared with one-way analysis of variance and post-hoc Newman-Keuls tests or two-way, unpaired t-tests.

\section{RESULTS}

Subjects included 53 diagnosed clinicopathologically with PD, 33 with ILBD and 111 who were clinically non-demented without parkinsonism and had no CNS $\alpha$-synuclein pathology (Table 1). The subjects were predominantly of advanced age, with the mean age ranges for the diagnostic groups falling between 83 and 87 years. Median disease duration for PD cases was 13 years, ranging from 2 to 44 years. PD cases were significantly younger $(\mathrm{p}<0.05)$ than normal or ILBD cases, were more likely to be male 
medRxiv preprint doi: https://doi.org/10.1101/2020.09.29.20204248; this version posted December 8, 2020. The copyright holder for this preprint (which was not certified by peer review) is the author/funder, who has granted medRxiv a license to display the preprint in perpetuity.

It is made available under a CC-BY-NC-ND 4.0 International license .

when compared to the normal group $(\mathrm{p}=0.006)$ and had higher UPDRS scores than the other groups $(\mathrm{p}<$ 0.0001). The mean postmortem intervals ranged between 4.1 and 4.6 hours and analysis of variance showed that there were no significant differences amongst groups. Vagus nerve was available for 26 ILBD, 36 PD and 111 normal control subjects. Stomach was available for 30 ILBD, 52 PD and 102 normal control subjects.

As in our previous investigations [1,17,77-79], only staining that was morphologically consistent with nerve fibers was considered to be specific for stomach or vagus nerve aSyn. Immunoreactive nerve fibers were present within the stomach or vagus nerve of 42/52 (81\%) and 32/36 (89\%) PD subjects, as compared to $5 / 30(17 \%)$ and 12/26 (46\%) of ILBD subjects (Table 2). No aSyn was present in stomach (102 subjects) or vagus nerve (111 subjects) of control subjects. Immunoreactive nerve fibers, when present in PD and ILBD subjects, were mostly sparse but occasionally focally frequent in the vagus nerve, and sometimes had abnormally large swollen segments, consistent with dystrophic change (Figure 1a, b). In the stomach, immunoreactive nerve fibers were found in all layers (Figure 2c-f) but most frequently were found in the submucosa, where they were often closely applied to the external surface of arterioles or within small nerve fascicles.

Cases, both ILBD and PD, that were aSyn-positive in stomach or vagus tended to have higher brain Unified LB stages and higher total brain aSyn loads than those that were aSyn negative, and, on average, ILBD cases with vagus or stomach aSyn were in USSLB Stage IIa or IIb (brainstem or limbicpredominant) while PD cases were most often in Stage III (brainstem and limbic), although some ILBD cases were in Stage III and some PD cases were in Stage IV (Table 2). All cases with vagus or stomach aSyn were in Unified Stage IIa (brainstem predominant), IIb (limbic predominant) or higher.

\section{DISCUSSION}

This is the first comprehensive assessment of the prevalence of stomach and vagus nerve aSyn in PD, ILBD and control subjects. The results show that stomach aSyn was present in $81 \%$ and vagus nerve 
medRxiv preprint doi: https://doi.org/10.1101/2020.09.29.20204248; this version posted December 8, 2020. The copyright holder for this preprint (which was not certified by peer review) is the author/funder, who has granted medRxiv a license to display the preprint in perpetuity. It is made available under a CC-BY-NC-ND 4.0 International license .

aSyn was present in $84 \%$ of autopsy confirmed PD subjects, while in ILBD, aSyn was present in stomach in only $17 \%$ and in vagus in only $46 \%$ of subjects. There was no aSyn found in either the stomach or vagus nerve from any of the more than 100 clinically normal control subjects without brain aSyn. The lack of aSyn in stomach and vagus nerve, in subjects without any brain aSyn, as well as the lesser prevalences of aSyn in stomach or vagus nerve as compared to brain (all of the PD and ILBD cases had brain aSyn), suggest that the spread of aSyn to the stomach and PNS occurs subsequent to the establishment of threshold brain aSyn loads. USSLB Stages and total brain aSyn loads were higher in ILBD and PD cases with stomach or vagus aSyn.

A critical question has been whether or not aSyn begins in the brain or within elements of the PNS [80-82]. The present results do not support the concept that the initiation of $\alpha$-synuclein pathology in Lewy body disorders begins in the PNS rather than the brain. Non-motor accompaniments of PD may predate or occur early in the motor progression [49,83-86] but the results for ILBD subjects suggest that even in these clinically prodromal subjects, aSyn has already been established in the brain. Autopsy studies of relatively small numbers of subjects with ILBD have demonstrated a high prevalence of aSyn within the spinal cord, sympathetic ganglia, adrenal medulla and upper GI tract $[1,7,11,26,42,43]$ but no study to date has found aSyn in the spinal cord or in PNS sites in the absence of brain involvement, with the possible exception of Fumimura et al (2007) [45] who reported one case out of 783 with adrenal medulla as the only site with aSyn. One other case report, by Miki et al (2009) [87] exists of Lewy body pathology restricted to the heart and stellate ganglion.

Although we used an immunohistochemical method that has been repeatedly demonstrated to be highly sensitive and specific for both CNS and PNS $\alpha$-synuclein pathology, as found in multi-center blinded studies $[69,70,78,88]$ and biochemical studies [75], it is possible that the initial form of peripheral $\alpha$-synuclein pathology may differ from that commonly seen in the CNS. Alternate forms may include non-phosphorylated $\alpha$-synuclein, truncated $\alpha$-synuclein [89-91] and $\alpha$-synuclein aggregates [39, 92]. 
medRxiv preprint doi: https://doi.org/10.1101/2020.09.29.20204248; this version posted December 8, 2020. The copyright holder for this preprint (which was not certified by peer review) is the author/funder, who has granted medRxiv a license to display the preprint in perpetuity.

It is made available under a CC-BY-NC-ND 4.0 International license .

Also, conversion of normal $\alpha$-synuclein to pathological varieties may occur more commonly in PNS locations other than stomach, perhaps on the basis of locally high normal $\alpha$-synuclein concentrations [19], or due to inflammation [93-95]. It is possible that the initial "seeding" of aSyn, whether from the environment or by spontaneous internal generation, is accomplished by transiently-existing forms that may not locally incite the more familiar forms of aSyn but do so in the CNS once transmitted there. Assessment of PNS with $\alpha$-synuclein seeding assays such as RT-QuIC or protein misfolding cyclic amplification (PMCA) may be more sensitive than IHC and may be more effective at uncovering PNS aSyn $[96,97]$. Recent studies have suggested that bidirectional spread of $\alpha$-synuclein aggregates may not necessarily pass through the vagus nerve but rather via a hematogenous route [61].

These results are most consistent with a first appearance of $\alpha$-synuclein pathology in the CNS, with later spread, often at a premotor stage, to the PNS. All cases with either vagus or stomach aSyn were in Unified Stage II (IIa or IIb) or a higher stage.

\section{ACKNOWLEDGMENTS}

This study was funded by grants from the National Institute of Neurological Disorders and Stroke (U24 NS072026) the National Institute on Aging (P30 AG19610), the Arizona Department of Health Services (contract 211002), the Arizona Biomedical Research Commission (contracts 4001, 0011, 05-901 and 1001) and the Michael J. Fox Foundation for Parkinson's Research. 
medRxiv preprint doi: https://doi.org/10.1101/2020.09.29.20204248; this version posted December 8, 2020. The copyright holder for this preprint (which was not certified by peer review) is the author/funder, who has granted medRxiv a license to display the preprint in perpetuity. It is made available under a CC-BY-NC-ND 4.0 International license .

Table 1. Clinical characteristics of study subjects, by clinicopathological diagnosis, age, sex, last motor UPDRS score and disease duration. Means and standard deviations (SD) are given. ILBD = incidental Lewy body disease; $\mathrm{PD}=$ Parkinson's disease; PMI = postmortem interval in hours; UPDRS = Unified Parkinson's Disease Rating Scale, Part III; Dis Dur = disease duration in years. * PD cases were significantly younger $(\mathrm{p}<0.05)$ than normal or ILBD cases, were more likely to be male when compared to the normal group $(\mathrm{p}<0.05)$ and had higher UPDRS scores $(\mathrm{p}<0.0001)$. The groups did not differ in terms of PMI.

\begin{tabular}{|l|c|c|c|c|c|}
\hline Diagnosis (N) & Age at Death* & Sex (\% male)* & PMI & UPDRS $^{*}$ & Dis Dur \\
\hline Normal (111) & $85.1(11.0)$ & 53.1 & $3.7(2.5)$ & $7.6(7.6)^{2}$ & N/A \\
\hline ILBD (33) & $86.3(8.2)$ & 57.6 & $4.5(4.2)$ & $8.0(6.2)^{3}$ & N/A \\
\hline PD (53) & $79.1(6.4)$ & 75.5 & $4.1(2.6)$ & $38.8(20.5)^{4}$ & $13.3(7.3)$ \\
\hline
\end{tabular}

1. Not all subjects had both vagus nerve and stomach available. See text for details.

2. For 15 normal cases, UPDRS scores were not available.

3. For 5 ILBD cases, UPDRS scores were not available.

4. For PD, 16 scores were done while on medication, 35 while off medication; 2 were not done.

Table 2. Neuropathological characteristics of Lewy body disease study subjects, by vagus and stomach aSyn status. Means and standard deviations (SD) are given. ILBD = incidental Lewy body disease; $P D=$ Parkinson's disease.

\begin{tabular}{|l|c|c|}
\hline Diagnosis & $\begin{array}{c}\text { USSLB Stage } \\
\text { Mean (SD) }\end{array}$ & $\begin{array}{c}\text { Brain aSyn Load } \\
\text { Mean (SD) }\end{array}$ \\
\hline ILBD: Vagus aSyn $+(\mathrm{n}=12)$ & $2.33(0.49)$ & $12.08(8.57)$ \\
\hline ILBD: Vagus aSyn $-(\mathrm{n}=14)^{1}$ & $1.92(0.64)$ & $6.08(6.79)$ \\
\hline ILBD: Stomach aSyn $+(\mathrm{n}=5)$ & $2.6(0.55)$ & $12.2(3.96)$ \\
\hline ILBD: Stomach aSyn - $(\mathrm{n}=25)^{1}$ & $1.96(0.69)$ & $7.92(8.30)$ \\
\hline PD: Vagus aSyn + $(\mathrm{n}=32)^{1}$ & $3.44(0.67)$ & $26.93(6.28)$ \\
\hline PD: Vagus aSyn - $(\mathrm{n}=4)$ & $3.25(0.96)$ & $25.75(11.56)$ \\
\hline PD: Stomach aSyn $+(\mathrm{n}=42)^{2}$ & $3.62(0.54)$ & $29.84(5.83)$ \\
\hline PD: Stomach aSyn $-(\mathrm{n}=10)$ & $3.0(0.67)$ & $22.33(5.81)$ \\
\hline
\end{tabular}

1. Missing USSLB stage and brain aSyn load for one case.

2. Missing brain aSyn load in three cases. 
medRxiv preprint doi: https://doi.org/10.1101/2020.09.29.20204248; this version posted December 8, 2020. The copyright holder for this preprint (which was not certified by peer review) is the author/funder, who has granted medRxiv a license to display the preprint in perpetuity. It is made available under a CC-BY-NC-ND 4.0 International license .

Figure 1. Photomicrographs of vagus nerve and stomach immunohistochemically stained for phosphorylated $\alpha$-synuclein (black) and counterstained with Neutral Red (red). A and B are longitudinal sections of vagus nerve at low (A) and medium (B) magnification. C and D show short fibers and puncta in the stomach mucosa. E shows short fibers applied to the peripheral surface on an arteriole in the submucosa. F shows puncta within an intermyenteric ganglion. Calibration bar in F represents $100 \mu \mathrm{m}$ for $\mathrm{C}-\mathrm{F}, 400 \mu \mathrm{m}$ for B and $800 \mu \mathrm{m}$ for $\mathrm{A}$.
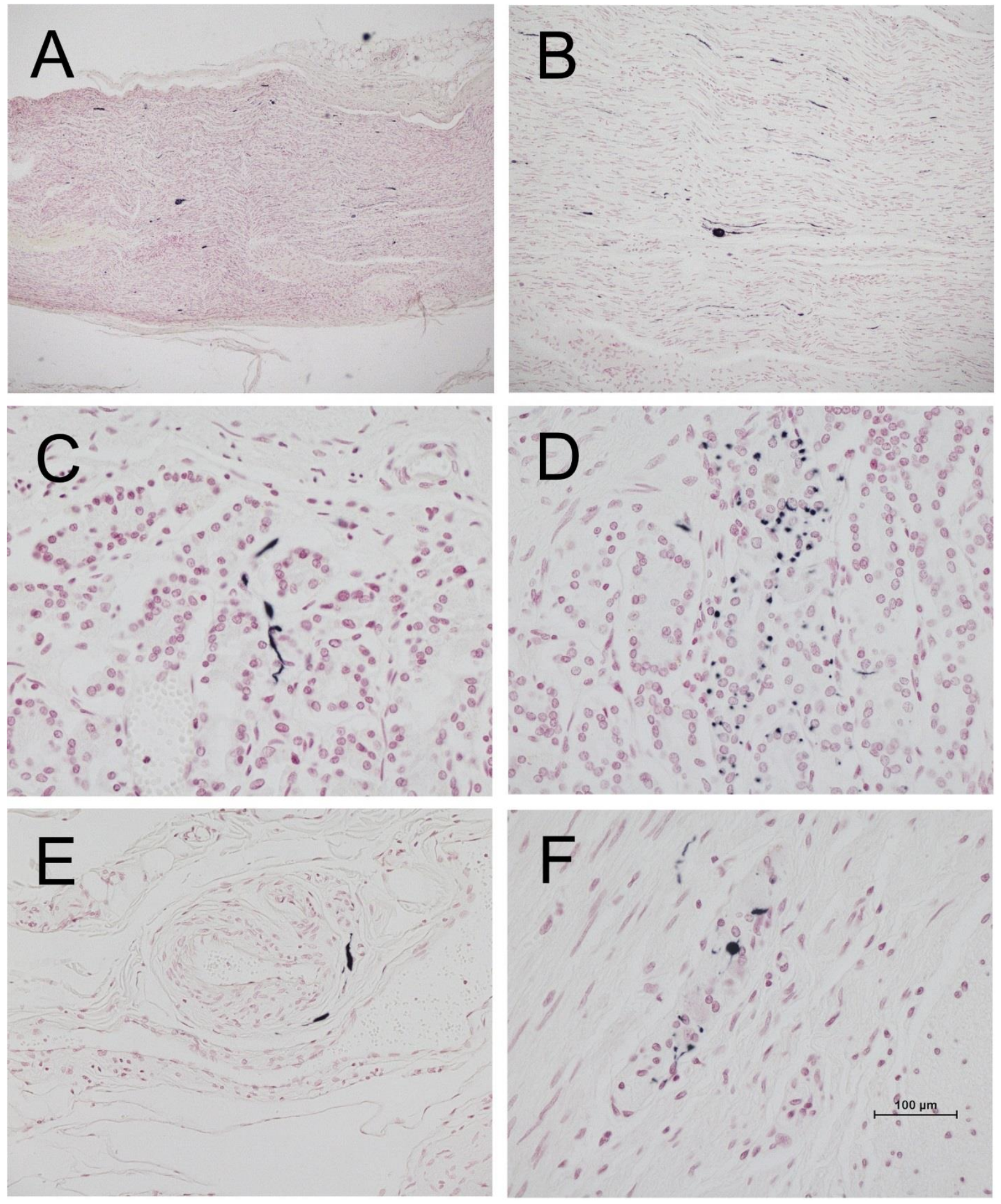
medRxiv preprint doi: https://doi.org/10.1101/2020.09.29.20204248; this version posted December 8, 2020. The copyright holder for this preprint (which was not certified by peer review) is the author/funder, who has granted medRxiv a license to display the preprint in perpetuity. It is made available under a CC-BY-NC-ND 4.0 International license .

\section{REFERENCES}

[1] Beach TG, Adler CH, Sue LI, Vedders L, Lue L, White Iii CL, Akiyama H, Caviness JN, Shill HA, Sabbagh MN, Walker DG (2010) Multi-organ distribution of phosphorylated alphasynuclein histopathology in subjects with Lewy body disorders. Acta Neuropathol 119, 689-702.

[2] Adler CH , Beach TG (2016) Neuropathological basis of nonmotor manifestations of Parkinson's disease. Mov Disord 31, 1114-1119.

[3] Adler CH, Beach TG, Zhang N, Shill HA, Driver-Dunckley E, Caviness JN, Mehta SH, Sabbagh MN, Serrano GE, Sue LI, Belden CM, Powell J, Jacobson SA, Zamrini E, Shprecher D, Davis KJ, Dugger BN, Hentz JG (2019) Unified Staging System for Lewy Body Disorders: Clinicopathologic Correlations and Comparison to Braak Staging. J Neuropathol Exp Neurol 78, 891-899.

[4] Beach TG, Adler CH, Lue L, Sue LI, Bachalakuri J, Henry-Watson J, Sasse J, Boyer S, Shirohi S, Brooks R, Eschbacher J, Akiyama H, Caviness J, Shill HA, Connor DJ, Sabbagh MN, Walker DG (2009) Unified staging system for Lewy body disorders: correlation with nigrostriatal degeneration, cognitive impairment and motor dysfunction. Acta Neuropathol 117, 613-634.

[5] Serrano GE, Shprecher D, Callan M, Cutler B, Glass M, Zhang N, Walker J, Intorcia A, Adler CH, Shill HA, Driver-Dunckley E, Mehta SH, Belden CM, Zamrini E, Sue LI, Vargas D, Beach TG (2020) Cardiac sympathetic denervation and synucleinopathy in Alzheimer's disease with brain Lewy body disease. Brain Commun 2 (in press).

[6] Travagli RA, Browning KN, Camilleri M (2020) Parkinson disease and the gut: new insights into pathogenesis and clinical relevance. Nat Rev Gastroenterol Hepatol (in press).

[7] Bloch A, Probst A, Bissig H, Adams H, Tolnay M (2006) Alpha-synuclein pathology of the spinal and peripheral autonomic nervous system in neurologically unimpaired elderly subjects. Neuropathol Appl Neurobiol 32, 284-295.

[8] Braak H, Bohl JR, Muller CM, Rub U, de Vos RA, Del TK (2006) Stanley Fahn Lecture 2005 : The staging procedure for the inclusion body pathology associated with sporadic Parkinson's disease reconsidered. Mov Disord 21, 2042-2051.

[9] Braak H, Ghebremedhin E, Rub U, Bratzke H, Del Tredici K (2004) Stages in the development of Parkinson's disease-related pathology. Cell Tissue Res 318, 121-134.

[10] Hishikawa N, Hashizume Y, Yoshida M, Sobue G (2003) Clinical and neuropathological correlates of Lewy body disease. Acta Neuropathol 105, 341-350.

[11] Klos KJ, Ahlskog JE, Josephs KA, Apaydin H, Parisi JE, Boeve BF, DeLucia MW, Dickson DW (2006) Alpha-synuclein pathology in the spinal cords of neurologically asymptomatic aged individuals. Neurology 66, 1100-1102. 
medRxiv preprint doi: https://doi.org/10.1101/2020.09.29.20204248; this version posted December 8, 2020. The copyright holder for this preprint (which was not certified by peer review) is the author/funder, who has granted medRxiv a license to display the preprint in perpetuity. It is made available under a CC-BY-NC-ND 4.0 International license .

[12] Wakabayashi K, Takahashi H, Takeda S, Ohama E, Ikuta F (1988) Parkinson's disease: the presence of Lewy bodies in Auerbach's and Meissner's plexuses. Acta Neuropathol 76, 217-221.

[13] Gelpi E, Navarro-Otano J, Tolosa E, Gaig C, Compta Y, Rey MJ, Marti MJ, Hernandez I, Valldeoriola F, Rene R, Ribalta T (2014) Multiple organ involvement by alpha-synuclein pathology in Lewy body disorders. Mov Disord 29, 1010-1018.

[14] Annerino DM, Arshad S, Taylor GM, Adler CH, Beach TG, Greene JG (2012) Parkinson's disease is not associated with gastrointestinal myenteric ganglion neuron loss. Acta Neuropathol 124, 665-680.

[15] Beach TG, Adler CH, Serrano G, Sue LI, Walker DG, Dugger BN, Shill HA, Driver-Dunckley E, Caviness JN, Intorcia A, Filon J, Scott S, Garcia A, Hoffman B, Belden CM, Davis KJ, Sabbagh MN (2016) Prevalence of submandibular gland synucleinopathy in Parkinson's disease, dementia with Lewy bodies and other Lewy body disorders. J Parkinsons Dis 6, 153-163.

[16] Beach TG, Corbille AG, Letournel F, Kordower JH, Kremer T, Munoz DG, Intorcia A, Hentz J, Adler CH, Sue LI, Walker J, Serrano G, Derkinderen P (2016) Multicenter Assessment of Immunohistochemical Methods for Pathological Alpha-Synuclein in Sigmoid Colon of Autopsied Parkinson's Disease and Control Subjects. J Parkinsons Dis 6, 761-770.

[17] Adler CH, Dugger BN, Hinni ML, Lott DG, Driver-Dunckley E, Hidalgo J, Henry-Watson J, Serrano G, Sue LI, Nagel T, Duffy A, Shill HA, Akiyama H, Walker DG, Beach TG (2014) Submandibular gland needle biopsy for the diagnosis of Parkinson disease. Neurology 82, 858-864.

[18] Fujishiro H, Frigerio R, Burnett M, Klos KJ, Josephs KA, Delledonne A, Parisi JE, Ahlskog JE, Dickson DW (2008) Cardiac sympathetic denervation correlates with clinical and pathologic stages of Parkinson's disease. Mov Disord 23, 1085-1092.

[19] Gray MT, Munoz DG, Gray DA, Schlossmacher MG, Woulfe JM (2014) Alpha-synuclein in the appendiceal mucosa of neurologically intact subjects. Mov Disord 29, 991-998.

[20] Hilton D, Stephens M, Kirk L, Edwards P, Potter R, Zajicek J, Broughton E, Hagan H, Carroll C (2014) Accumulation of alpha-synuclein in the bowel of patients in the pre-clinical phase of Parkinson's disease. Acta Neuropathol 127, 235-241.

[21] Ito S, Takao M, Hatsuta H, Kanemaru K, Arai T, Saito Y, Fukayama M, Murayama S (2014) Alpha-synuclein immunohistochemistry of gastrointestinal and biliary surgical specimens for diagnosis of Lewy body disease. Int J Clin Exp Pathol 7, 1714-1723.

[22] Lebouvier T, Neunlist M, Bruley d, V, Coron E, Drouard A, N'Guyen JM, Chaumette T, Tasselli M, Paillusson S, Flamand M, Galmiche JP, Damier P, Derkinderen P (2010) Colonic biopsies to assess the neuropathology of Parkinson's disease and its relationship with symptoms. PLoS One 5, e12728- 
medRxiv preprint doi: https://doi.org/10.1101/2020.09.29.20204248; this version posted December 8, 2020. The copyright holder for this preprint (which was not certified by peer review) is the author/funder, who has granted medRxiv a license to display the preprint in perpetuity. It is made available under a CC-BY-NC-ND 4.0 International license .

[23] Lebouvier T, Chaumette T, Damier P, Coron E, Touchefeu Y, Vrignaud S, Naveilhan P, Galmiche JP, Bruley d, V, Derkinderen P, Neunlist M (2008) Pathological lesions in colonic biopsies during Parkinson's disease. Gut 57, 1741-1743.

[24] Lee JM, Derkinderen P, Kordower JH, Freeman R, Munoz DG, Kremer T, Zago W, Hutten SJ, Adler CH, Serrano GE, Beach TG (2017) The Search for a Peripheral Biopsy Indicator of alpha-Synuclein Pathology for Parkinson Disease. J Neuropathol Exp Neurol 76, 2-15.

[25] Lionnet A, Leclair-Visonneau L, Neunlist M, Murayama S, Takao M, Adler CH, Derkinderen P, Beach TG (2018) Does Parkinson's disease start in the gut? Acta Neuropathol 135, 1-12.

[26] Minguez-Castellanos A, Chamorro CE, Escamilla-Sevilla F, Ortega-Moreno A, Rebollo AC, Gomez-Rio M, Concha A, Munoz DG (2007) Do alpha-synuclein aggregates in autonomic plexuses predate Lewy body disorders?: a cohort study. Neurology 68, 2012-2018.

[27] Mu L, Sobotka S, Chen J, Su H, Sanders I, Nyirenda T, Adler CH, Shill HA, Caviness JN, Samanta JE, Sue LI, Beach TG (2013) Parkinson disease affects peripheral sensory nerves in the pharynx. J Neuropathol Exp Neurol 72, 614-623.

[28] Mu L, Sobotka S, Chen J, Su H, Sanders I, Adler CH, Shill HA, Caviness JN, Samanta JE, Beach TG (2013) Alpha-synuclein pathology and axonal degeneration of the peripheral motor nerves innervating pharyngeal muscles in Parkinson disease. J Neuropathol Exp Neurol 72, 119-129.

[29] Mu L, Chen J, Sobotka S, Nyirenda T, Benson B, Gupta F, Sanders I, Adler CH, Caviness JN, Shill HA, Sabbagh M, Samanta JE, Sue LI, Beach TG (2015) Alpha-Synuclein Pathology in Sensory Nerve Terminals of the Upper Aerodigestive Tract of Parkinson's Disease Patients. Dysphagia 30, 404-417.

[30] Orimo S, Uchihara T, Nakamura A, Mori F, Kakita A, Wakabayashi K, Takahashi H (2008) Axonal alpha-synuclein aggregates herald centripetal degeneration of cardiac sympathetic nerve in Parkinson's disease. Brain 131, 642-650.

[31] Pouclet H, Lebouvier T, Coron E, Des Varannes SB, Rouaud T, Roy M, Neunlist M, Derkinderen $\mathrm{P}$ (2012) A comparison between rectal and colonic biopsies to detect Lewy pathology in Parkinson's disease. Neurobiol Dis 45, 305-309.

[32] Sanchez-Ferro A, Rabano A, Catalan MJ, Rodriguez-Valcarcel FC, Fernandez DS, HerrerosRodriguez J, Garcia-Cobos E, Alvarez-Santullano MM, Lopez-Manzanares L, Mosqueira AJ, Vela DL, Lopez-Lozano JJ, Lopez-Valdes E, Sanchez-Sanchez R, Molina-Arjona JA (2015) In vivo gastric detection of alpha-synuclein inclusions in Parkinson's disease. Mov Disord 30, 517-524.

[33] Schneider SA, Boettner M, Alexoudi A, Zorenkov D, Deuschl G, Wedel T (2016) Can we use peripheral tissue biopsies to diagnose Parkinson's disease? A review of the literature. Eur $J$ Neurol 23, 247-261.

[34] Serrano GE, Shprecher D, Callan M, Cutler B, Glass M, Zhang N, Walker J, Intorcia A, Adler CH, Shill HA, Driver-Dunckley E, Mehta SH, Belden CM, Zamrini E, Sue LI, Vargas D, 
medRxiv preprint doi: https://doi.org/10.1101/2020.09.29.20204248; this version posted December 8, 2020. The copyright holder for this preprint (which was not certified by peer review) is the author/funder, who has granted medRxiv a license to display the preprint in perpetuity. It is made available under a CC-BY-NC-ND 4.0 International license .

Beach TG (2020) Cardiac sympathetic denervation and synucleinopathy in Alzheimer's disease with brain Lewy body disease. Brain Commun 2 (in press).

[35] Shannon KM, Keshavarzian A, Dodiya HB, Jakate S, Kordower JH (2012) Is alpha-synuclein in the colon a biomarker for premotor Parkinson's Disease? Evidence from 3 cases. Mov Disord 27, 716-719.

[36] Shannon KM, Keshavarzian A, Mutlu E, Dodiya HB, Daian D, Jaglin JA, Kordower JH (2012) Alpha-synuclein in colonic submucosa in early untreated Parkinson's disease. Mov Disord 27, 709-715.

[37] Sprenger FS, Stefanova N, Gelpi E, Seppi K, Navarro-Otano J, Offner F, Vilas D, Valldeoriola F, Pont-Sunyer C, Aldecoa I, Gaig C, Gines A, Cuatrecasas M, Hogl B, Frauscher B, Iranzo A, Wenning GK, Vogel W, Tolosa E, Poewe W (2015) Enteric nervous system alphasynuclein immunoreactivity in idiopathic REM sleep behavior disorder. Neurology $\mathbf{8 5}$, 1761-1768.

[38] Vilas D, Iranzo A, Tolosa E, Aldecoa I, Berenguer J, Vilaseca I, Marti C, Serradell M, Lomena F, Alos L, Gaig C, Santamaria J, Gelpi E (2016) Assessment of alpha-synuclein in submandibular glands of patients with idiopathic rapid-eye-movement sleep behaviour disorder: a case-control study. Lancet Neurol

[39] Visanji NP, Marras C, Kern DS, Al DA, Gao A, Liu LW, Lang AE, Hazrati LN (2015) Colonic mucosal a-synuclein lacks specificity as a biomarker for Parkinson disease. Neurology $\mathbf{8 4}$, 609-616.

[40] Wang N, Gibbons CH, Lafo J, Freeman R (2013) alpha-Synuclein in cutaneous autonomic nerves. Neurology 81, 1604-1610.

[41] Takeda S, Yamazaki K, Miyakawa T, Arai H (1993) Parkinson's disease with involvement of the parasympathetic ganglia. Acta Neuropathol 86, 397-398.

[42] Braak H, Sastre M, Bohl JR, de Vos RA, Del TK (2007) Parkinson's disease: lesions in dorsal horn layer I, involvement of parasympathetic and sympathetic pre- and postganglionic neurons. Acta Neuropathol 113, 421-429.

[43] Braak H, de Vos RA, Bohl J, Del TK (2006) Gastric alpha-synuclein immunoreactive inclusions in Meissner's and Auerbach's plexuses in cases staged for Parkinson's disease-related brain pathology. Neurosci Lett 396, 67-72.

[44] Koike Y, Takahashi A (1997) Autonomic dysfunction in Parkinson's disease. Eur Neurol 38 Suppl 2, 8-12.

[45] Fumimura Y, Ikemura M, Saito Y, Sengoku R, Kanemaru K, Sawabe M, Arai T, Ito G, Iwatsubo T, Fukayama M, Mizusawa H, Murayama S (2007) Analysis of the adrenal gland is useful for evaluating pathology of the peripheral autonomic nervous system in lewy body disease. J Neuropathol Exp Neurol 66, 354-362. 
medRxiv preprint doi: https://doi.org/10.1101/2020.09.29.20204248; this version posted December 8, 2020. The copyright holder for this preprint (which was not certified by peer review) is the author/funder, who has granted medRxiv a license to display the preprint in perpetuity. It is made available under a CC-BY-NC-ND 4.0 International license .

[46] Hishikawa N, Hashizume Y, Hirayama M, Imamura K, Washimi Y, Koike Y, Mabuchi C, Yoshida M, Sobue G (2000) Brainstem-type Lewy body disease presenting with progressive autonomic failure and lethargy. Clin Auton Res 10, 139-143.

[47] den Hartog Jager WA, Bethlem J (1960) The distribution of Lewy bodies in the central and autonomic nervous systems in idiopathic paralysis agitans. J Neurol Neurosurg Psychiatry 23, 283-290.

[48] Verbaan D, Marinus J, Visser M, van Rooden SM, Stiggelbout AM, van Hilten JJ (2007) Patientreported autonomic symptoms in Parkinson disease. Neurology 69, 333-341.

[49] Siddiqui MF, Rast S, Lynn MJ, Auchus AP, Pfeiffer RF (2002) Autonomic dysfunction in Parkinson's disease: a comprehensive symptom survey. Parkinsonism Relat Disord 8, 277284.

[50] Adler CH (2005) Nonmotor complications in Parkinson's disease. Mov Disord 20 Suppl 11, S23S29.

[51] Edwards LL, Quigley EM, Pfeiffer RF (1992) Gastrointestinal dysfunction in Parkinson's disease: frequency and pathophysiology. Neurology 42, 726-732.

[52] Greene JG, Noorian AR, Srinivasan S (2009) Delayed gastric emptying and enteric nervous system dysfunction in the rotenone model of Parkinson's disease. Exp Neurol 218, 154161.

[53] Hopkins DA, Bieger D, deVente J, Steinbusch WM (1996) Vagal efferent projections: viscerotopy, neurochemistry and effects of vagotomy. Prog Brain Res 107, 79-96.

[54] Gray MT, Munoz DG, Schlossmacher MG, Gray DA, Woulfe JM (2015) Protective effect of vagotomy suggests source organ for Parkinson's disease. Ann Neurol 78, 834-835.

[55] Borghammer P , Hamani C (2017) Preventing Parkinson disease by vagotomy: Fact or fiction? Neurology 88, 1982-1983.

[56] Liu B, Fang F, Pedersen NL, Tillander A, Ludvigsson JF, Ekbom A, Svenningsson P, Chen H, Wirdefeldt K (2017) Vagotomy and Parkinson disease: A Swedish register-based matchedcohort study. Neurology 88, 1996-2002.

[57] Svensson E, Horvath-Puho E, Thomsen RW, Djurhuus JC, Pedersen L, Borghammer P, Sorensen HT (2015) Does vagotomy reduce the risk of Parkinson's disease: The authors reply. Ann Neurol 78, 1012-1013.

[58] Svensson E, Horvath-Puho E, Thomsen RW, Djurhuus JC, Pedersen L, Borghammer P, Sorensen HT (2015) Vagotomy and subsequent risk of Parkinson's disease. Ann Neurol 78, 522-529.

[59] Tysnes OB, Kenborg L, Herlofson K, Steding-Jessen M, Horn A, Olsen JH, Reichmann H (2015) Does vagotomy reduce the risk of Parkinson's disease? Ann Neurol 78, 1011-1012.

[60] Van Den Berge N, Ferreira N, Gram H, Mikkelsen TW, Alstrup AKO, Casadei N, Tsung-Pin P, Riess O, Nyengaard JR, Tamguney G, Jensen PH, Borghammer P (2019) Evidence for 
medRxiv preprint doi: https://doi.org/10.1101/2020.09.29.20204248; this version posted December 8, 2020. The copyright holder for this preprint (which was not certified by peer review) is the author/funder, who has granted medRxiv a license to display the preprint in perpetuity. It is made available under a CC-BY-NC-ND 4.0 International license.

bidirectional and trans-synaptic parasympathetic and sympathetic propagation of alphasynuclein in rats. Acta Neuropathol 138, 535-550.

[61] Arotcarena ML, Dovero S, Prigent A, Bourdenx M, Camus S, Porras G, Thiolat ML, Tasselli M, Aubert P, Kruse N, Mollenhauer B, Trigo D, I, Estrada C, Garcia-Carrillo N, Vaikath NN, El-Agnaf OMA, Herrero MT, Vila M, Obeso JA, Derkinderen P, Dehay B, Bezard E (2020) Bidirectional gut-to-brain and brain-to-gut propagation of synucleinopathy in nonhuman primates. Brain 143, 1462-1475.

[62] Leclair-Visonneau L, Neunlist M, Derkinderen P, Lebouvier T (2020) The gut in Parkinson's disease: Bottom-up, top-down, or neither? Neurogastroenterol Motil 32, e13777-

[63] Beach TG, Adler CH, Sue LI, Peirce JB, Bachalakuri J, sing-Hernandez JE, Lue LF, Caviness JN, Connor DJ, Sabbagh MN, Walker DG (2008) Reduced striatal tyrosine hydroxylase in incidental Lewy body disease. Acta Neuropathol 115, 445-451.

[64] Delledonne A, Klos KJ, Fujishiro H, Ahmed Z, Parisi JE, Josephs KA, Frigerio R, Burnett M, Wszolek ZK, Uitti RJ, Ahlskog JE, Dickson DW (2008) Incidental Lewy body disease and preclinical Parkinson disease. Arch Neurol 65, 1074-1080.

[65] Dickson DW, Fujishiro H, Delledonne A, Menke J, Ahmed Z, Klos KJ, Josephs KA, Frigerio R, Burnett M, Parisi JE, Ahlskog JE (2008) Evidence that incidental Lewy body disease is pre-symptomatic Parkinson's disease. Acta Neuropathol 115, 437-444.

[66] Beach TG, Adler CH, Sue LI, Serrano G, Shill HA, Walker DG, Lue L, Roher AE, Dugger BN, Maarouf C, Birdsill AC, Intorcia A, Saxon-Labelle M, Pullen J, Scroggins A, Filon J, Scott S, Hoffman B, Garcia A, Caviness JN, Hentz JG, Driver-Dunckley E, Jacobson SA, Davis KJ, Belden CM, Long KE, Malek-Ahmadi M, Powell JJ, Gale LD, Nicholson LR, Caselli RJ, Woodruff BK, Rapscak SZ, Ahern GL, Shi J, Burke AD, Reiman EM, Sabbagh MN (2015) Arizona Study of Aging and Neurodegenerative Disorders and Brain and Body Donation Program. Neuropathology 35, 354-389.

[67] Beach TG, Serrano GE, Kremer T, Canamero M, Dziadek S, Sade H, Derkinderen P, Corbille AG, Letournel F, Munoz DG, White CL, III, Schneider J, Crary JF, Sue LI, Adler CH, Glass MJ, Intorcia AJ, Walker JE, Foroud T, Coffey CS, Ecklund D, Riss H, Gossmann J, Konig F, Kopil CM, Arnedo V, Riley L, Linder C, Dave KD, Jennings D, Seibyl J, Mollenhauer B, Chahine L (2018) Immunohistochemical Method and Histopathology Judging for the Systemic Synuclein Sampling Study (S4). J Neuropathol Exp Neurol 77, 793-802.

[68] Lee JM, Derkinderen P, Kordower JH, Freeman R, Munoz DG, Kremer T, Zago W, Hutten SJ, Adler CH, Serrano GE, Beach TG (2017) The Search for a Peripheral Biopsy Indicator of alpha-Synuclein Pathology for Parkinson Disease. J Neuropathol Exp Neurol 76, 2-15.

[69] Beach TG, White CL, Hamilton RL, Duda JE, Iwatsubo T, Dickson DW, Roncaroli F, Buttini M, Hladik CL, Sue LI, Noorigian JV, Adler CH (2008) Evaluation of alpha-synuclein immunohistochemical methods used by invited experts. Acta Neuropathol 116, 277-288.

[70] Corbille AG, Letournel F, Kordower JH, Lee J, Shanes E, Neunlist M, Munoz DG, Derkinderen P, Beach TG (2016) Evaluation of alpha-synuclein immunohistochemical methods for the 
medRxiv preprint doi: https://doi.org/10.1101/2020.09.29.20204248; this version posted December 8, 2020. The copyright holder for this preprint (which was not certified by peer review) is the author/funder, who has granted medRxiv a license to display the preprint in perpetuity. It is made available under a CC-BY-NC-ND 4.0 International license.

detection of Lewy-type synucleinopathy in gastrointestinal biopsies. Acta Neuropathol Commun 4, 35-

[71] Lue LF, Walker DG, Adler CH, Shill H, Tran H, Akiyama H, Sue LI, Caviness J, Sabbagh MN, Beach TG (2012) Biochemical Increase in Phosphorylated Alpha-Synuclein Precedes Histopathology of Lewy-Type Synucleinopathies. Brain Pathol 22, 745-756.

[72] Fujiwara H, Hasegawa M, Dohmae N, Kawashima A, Masliah E, Goldberg MS, Shen J, Takio K, Iwatsubo T (2002) alpha-Synuclein is phosphorylated in synucleinopathy lesions. Nat Cell Biol 4, 160-164.

[73] Obi K, Akiyama H, Kondo H, Shimomura Y, Hasegawa M, Iwatsubo T, Mizuno Y, Mochizuki H (2008) Relationship of phosphorylated alpha-synuclein and tau accumulation to Abeta deposition in the cerebral cortex of dementia with Lewy bodies. Exp Neurol 210, 409-420.

[74] Beach TG, Adler CH, Sue LI, Serrano G, Shill HA, Walker DG, Lue L, Roher AE, Dugger BN, Maarouf C, Birdsill AC, Intorcia A, Saxon-Labelle M, Pullen J, Scroggins A, Filon J, Scott S, Hoffman B, Garcia A, Caviness JN, Hentz JG, Driver-Dunckley E, Jacobson SA, Davis KJ, Belden CM, Long KE, Malek-Ahmadi M, Powell JJ, Gale LD, Nicholson LR, Caselli RJ, Woodruff BK, Rapscak SZ, Ahern GL, Shi J, Burke AD, Reiman EM, Sabbagh MN (2015) Arizona Study of Aging and Neurodegenerative Disorders and Brain and Body Donation Program. Neuropathology 35, 354-389.

[75] Walker DG, Lue LF, Adler CH, Shill HA, Caviness JN, Sabbagh MN, Akiyama H, Serrano GE, Sue LI, Beach TG (2013) Changes in properties of serine 129 phosphorylated alphasynuclein with progression of Lewy-type histopathology in human brains. Exp Neurol 240, 190-204.

[76] Beach TG, Adler CH, Sue LI, Vedders L, Lue L, White Iii CL, Akiyama H, Caviness JN, Shill HA, Sabbagh MN, Walker DG (2010) Multi-organ distribution of phosphorylated alphasynuclein histopathology in subjects with Lewy body disorders. Acta Neuropathol

[77] Beach TG, Adler CH, Dugger BN, Serrano G, Hidalgo J, Henry-Watson J, Shill HA, Sue LI, Sabbagh MN, Akiyama H (2013) Submandibular gland biopsy for the diagnosis of Parkinson disease. J Neuropathol Exp Neurol 72, 130-136.

[78] Beach TG, Serrano GE, Kremer T, Canamero M, Dziadek S, Sade H, Derkinderen P, Corbille AG, Letournel F, Munoz DG, White CL, III, Schneider J, Crary JF, Sue LI, Adler CH, Glass MJ, Intorcia AJ, Walker JE, Foroud T, Coffey CS, Ecklund D, Riss H, Gossmann J, Konig F, Kopil CM, Arnedo V, Riley L, Linder C, Dave KD, Jennings D, Seibyl J, Mollenhauer B, Chahine L (2018) Immunohistochemical Method and Histopathology Judging for the Systemic Synuclein Sampling Study (S4). J Neuropathol Exp Neurol 77, 793-802.

[79] Chahine LM, Beach TG, Brumm MC, Adler CH, Coffey CS, Mosovsky S, Caspell-Garcia C, Serrano GE, Munoz DG, White CL, III, Crary JF, Jennings D, Taylor P, Foroud T, Arnedo V, Kopil CM, Riley L, Dave KD, Mollenhauer B (2020) In vivo distribution of alphasynuclein in multiple tissues and biofluids in Parkinson disease. Neurology (in press).

[80] Langston JW (2006) The Parkinson's complex: parkinsonism is just the tip of the iceberg. Ann Neurol 59, 591-596. 
medRxiv preprint doi: https://doi.org/10.1101/2020.09.29.20204248; this version posted December 8, 2020. The copyright holder for this preprint (which was not certified by peer review) is the author/funder, who has granted medRxiv a license to display the preprint in perpetuity. It is made available under a CC-BY-NC-ND 4.0 International license.

[81] Braak H, Rub U, Gai WP, Del TK (2003) Idiopathic Parkinson's disease: possible routes by which vulnerable neuronal types may be subject to neuroinvasion by an unknown pathogen. $J$ Neural Transm 110, 517-536.

[82] Hawkes CH, Del TK, Braak H (2007) Parkinson's disease: a dual-hit hypothesis. Neuropathol Appl Neurobiol 33, 599-614.

[83] Kaufmann H, Nahm K, Purohit D, Wolfe D (2004) Autonomic failure as the initial presentation of Parkinson disease and dementia with Lewy bodies. Neurology 63, 1093-1095.

[84] Petrovitch H, Abbott RD, Ross GW, Nelson J, Masaki KH, Tanner CM, Launer LJ, White LR. Bowel movement frequency in late-life and substantia nigra neuron density at death. Mov Disord. 2009 Feb 15;24(3):371-6.

[85] Abbott RD, Petrovitch H, White LR, Masaki KH, Tanner CM, Curb JD, Grandinetti A, Blanchette PL, Popper JS, Ross GW (2001) Frequency of bowel movements and the future risk of Parkinson's disease. Neurology 57, 456-462.

[86] Pfeiffer RF (2003) Gastrointestinal dysfunction in Parkinson's disease. Lancet Neurol 2, 107-116.

[87] Miki Y, Mori F, Wakabayashi K, Kuroda N, Orimo S (2009) Incidental Lewy body disease restricted to the heart and stellate ganglia. Mov Disord 24, 2299-2301.

[88] Beach TG, Corbille AG, Letournel F, Kordower JH, Kremer T, Munoz DG, Intorcia A, Hentz J, Adler CH, Sue LI, Walker J, Serrano G, Derkinderen P (2016) Multicenter Assessment of Immunohistochemical Methods for Pathological Alpha-Synuclein in Sigmoid Colon of Autopsied Parkinson's Disease and Control Subjects. J Parkinsons Dis 6, 761-770.

[89] Sorrentino ZA, Giasson BI (2020) The emerging role of alpha-synuclein truncation in aggregation and disease. J Biol Chem 295, 10224-10244.

[90] Ahn EH, Kang SS, Liu X, Chen G, Zhang Z, Chandrasekharan B, Alam AM, Neish AS, Cao X, Ye K (2020) Initiation of Parkinson's disease from gut to brain by delta-secretase. Cell Res 30, $70-87$.

[91] Prasad K, Beach TG, Hedreen J, Richfield EK (2012) Critical role of truncated alpha-synuclein and aggregates in Parkinson's disease and incidental Lewy body disease. Brain Pathol 22, 811-825.

[92] Bourdenx M, Nioche A, Dovero S, Arotcarena ML, Camus S, Porras G, Thiolat ML, Rougier NP, Prigent A, Aubert P, Bohic S, Sandt C, Laferriere F, Doudnikoff E, Kruse N, Mollenhauer B, Novello S, Morari M, Leste-Lasserre T, Damas IT, Goillandeau M, Perier C, Estrada C, Garcia-Carrillo N, Recasens A, Vaikath NN, El-Agnaf OMA, Herrero MT, Derkinderen P, Vila M, Obeso JA, Dehay B, Bezard E (2020) Identification of distinct pathological signatures induced by patient-derived alpha-synuclein structures in nonhuman primates. Sci Adv 6, eaaz9165-

[93] Resnikoff H, Metzger JM, Lopez M, Bondarenko V, Mejia A, Simmons HA, Emborg ME (2019) Colonic inflammation affects myenteric alpha-synuclein in nonhuman primates. $J$ Inflamm Res 12, 113-126. 
medRxiv preprint doi: https://doi.org/10.1101/2020.09.29.20204248; this version posted December 8, 2020. The copyright holder for this preprint

(which was not certified by peer review) is the author/funder, who has granted medRxiv a license to display the preprint in perpetuity.

It is made available under a CC-BY-NC-ND 4.0 International license.

[94] Devos D, Lebouvier T, Lardeux B, Biraud M, Rouaud T, Pouclet H, Coron E, Bruley d, V, Naveilhan P, Nguyen JM, Neunlist M, Derkinderen P (2013) Colonic inflammation in Parkinson's disease. Neurobiol Dis 50, 42-48.

[95] Rolli-Derkinderen M, Leclair-Visonneau L, Bourreille A, Coron E, Neunlist M, Derkinderen P (2020) Is Parkinson's disease a chronic low-grade inflammatory bowel disease? J Neurol 267, 2207-2213.

[96] Fenyi A, Leclair-Visonneau L, Clairembault T, Coron E, Neunlist M, Melki R, Derkinderen P, Bousset L (2019) Detection of alpha-synuclein aggregates in gastrointestinal biopsies by protein misfolding cyclic amplification. Neurobiol Dis 129, 38-43.

[97] Manne S, Kondru N, Jin H, Serrano GE, Anantharam V, Kanthasamy A, Adler CH, Beach TG, Kanthasamy AG (2020) Blinded RT-QuIC analysis of $\alpha$-synuclein biomarker in skin tissue from Parkinson's disease patients. Mov Disord (in press). 